\title{
Potential of RAPD markers for identification of fruit types of Artocarpus heterophyllus Lam. (jackfruit)
}

\author{
D.K.N.G. Pushpakumara ${ }^{1 *}$ and S.A. Harris ${ }^{2}$ \\ Department of Crop Science, Faculty of Agriculture, University of Peradeniya, Peradeniya. \\ Oxford Forestry Institute, Department of Plant Sciences, South Parks Road, Oxford OXI 3RB, UK.
}

Revised: 20 December 2006 ; Accepted: 20 March 2007

\begin{abstract}
Artocarpus heterophyllus Lam. (jackfruit) of the family Moraceae is considered to be a native species of the rainforests of the western Ghats of India and the Malaysian Archipelago. It has been introduced to South and South East Asian countries and now is widely spread in tropical Asia, including Sri Lanka, as an important fruit and timber tree. It produces two fruit types, which can only be differentiated when ripened syncarps are dissected. Of the two types, the hard-fleshed fruit type (varaka) is favoured over the soft-fleshed fruit type (vella). An experiment was carried out to identify Random Amplification of Polymorphic DNA (RAPD) markers to differentiate the two fruit types of $A$. heterophyllus. Results of the RAPD analysis revealed that the two fruit types may be distinguished from one RAPD product, namely OPB-01-1.0. Development of Sequence Characterized Amplified Region SCAR markers for easy and effective identification is suggested.
\end{abstract}

Keywords: Artocarpus heterophyllus, jackfruit, RAPD markers, hard-fleshed and soft-fleshed fruit types.

\section{INTRODUCTION}

Artocarpus heterophyllus Lam. (Jackfruit) is a member of the family Moraceae. It is considered to be a native species of the rainforests of the western Ghats of India and the Malaysian Archipelago ${ }^{1-4}$. It has been introduced to South and Southeast Asian countries and is now widely spread in tropical Asia, including Sri Lanka, as an important fruit and timber tree. Two fruit types could be found in $A$. heterophyllus which vary in the firmness of the edible flesh of the ripened fruit ${ }^{1-6}$. The hard-fleshed fruit type (varaka, VK) is preferred over the soft-fleshed fruit type (vella, VL). Variation in flesh texture between the two fruit types has not been consistent through generations and seeds planted from either fruit type yields a mixture of types ${ }^{5}$. However, little is known about their pattern of segregation. Seedlings of different fruit types of $A$. heterophyllus cannot be morphologically differentiated and is possible only when ripe syncarps are produced, which generally takes eight to ten years from planting 5 . Identification of fruit types of A. heterophyllus at the seedling stage is useful in the management of genetic resources for conservation and genetic improvement programmes.

Advances in the genetic markers such as isozymes ${ }^{7}$ restriction fragment length polymorphisms (RFLPs) ${ }^{8}$ and polymerase chain reaction (PCR) based methods ${ }^{9-12}$ are more reliable for identification of genetic diversity than morphological markers ${ }^{13}$ although each technique has advantages and limitations. These molecular markers can be linked to important traits, and used for early selection of potentially desirable genotypes and individuals ${ }^{13-15}$.

Polymorphism detected by randomly amplified polymorphic DNA (RAPD) has proved to be useful for identifying variation at different levels ${ }^{16-21}$ in Carica papaya $^{17}$, Ficus carica ${ }^{18}$, Malus domestica ${ }^{19}$, Mangifera indica $^{20}$ and Theobroma cacao $^{21}$. Limitations of the RAPD technique, such as poor reproducibility, sensitivity to amplification conditions, different genomic backgrounds of the amplification products and homology of co-migrated products, have been discussed by Ayliffe et al. ${ }^{22}$, Ellsworth et al. ${ }^{23}$, Harris ${ }^{24}$ and Williams et al. ${ }^{11}$.The reproducibility of RAPD results may be overcome by optimizing experimental conditions and following precisely a chosen experimental protocol. Further, RAPD is a less expensive technique compared to others. Hence, this study was carried out to identify RAPD markers that can differentiate the two fruit types, VK and VL in A. heterophyllus. 


\section{METHODS AND MATERIALS}

Plant material: Leaf material was obtained from trees of known VK and VL types in a naturalized population at Dodangolla. Immature leaf samples $(2 \mathrm{~cm} \mathrm{x} 2 \mathrm{~cm})$ were collected from 35 trees of each fruit type. Leaf samples were placed in labelled re-sealable plastic bags with silica gel for drying. After $24 \mathrm{~h}$, silica gel was removed and the bags of dried leaf samples were stored at $-20^{\circ} \mathrm{C}$ until DNA extraction.

DNA extraction and amplification: Total DNA was extracted using Doyle and Doyle ${ }^{26}$ approach and DNA extraction and amplification were carried out as described by Pushpakumara et $a l^{27}$. To determine the optimum amplification conditions and also to ensure the reproducibility of the results, the reaction conditions were standardized using a study and tested at least twice. This study was carried out with five primers (OPB-01 to OPB-05) using a range of DNA concentrations $(0.5,1$ and $2 \mu \mathrm{l}$ from original DNA extracts, $1: 10,1: 50$ and $1: 100$ dilutions $)$ and two annealing temperatures $\left(33\right.$ and $35^{\circ} \mathrm{C}$ ). In order to identify any markers that distinguish the two fruit types DNA extracts from two trees of each VK and VL type were screened with 100 primers (Operon kits A, B, E, H and X).

Separation of amplification products: Products generated by amplification were separated on $2 \%(\mathrm{w} / \mathrm{v})$ agarose gels (Sigma, A6013) prepared with $5 \mathrm{~g}$ of agarose in $250 \mathrm{~mL}$ of $1 \mathrm{x}$ staphylococcal enterotoxin B (SEB) and stained with ethidium bromide $(0.5 \mu \mathrm{g} / \mathrm{mL})$. Ten $\mu \mathrm{L}$ of each amplification product, mixed with $1 \mu \mathrm{L}$ of bromophenol blue, was loaded into the wells of the gel. A 123 bp marker ladder (Life Technologies) was used to determine the size of the resulting amplified DNA products. Gels were electrophoresed at $100 \mathrm{~V}$ and $300 \mathrm{~mA}$ for $3 \mathrm{~h}$. After staining for $10 \mathrm{~min}$ in ethidium bromide solution $(1 \mu \mathrm{L} / \mathrm{mL})$, the products were visualized on a UV transilluminator and photographed using Polaroid 667 film. Each amplified product was named by the primer used and size of the product. RAPD data was scored for the presence $(+)$ or absence (-) of products irrespective of the intensity of the product. Amplification products over $1.9 \mathrm{~kb}$ were not reproducible, and thus were not scored in the study.

\section{RESULTS}

\section{DNA extraction and optimum PCR conditions}

Genomic DNA was successfully extracted from silica geldried leaf samples of $A$. heterophyllus trees, using a modified cetyl trimethyl ammonium bromide (CTAB) procedure. The approximate DNA concentration in the extracts was $12 \eta \mathrm{g} / \mu \mathrm{L}$. The original concentration of the
DNA extracts was too high for reliable amplification, showing poor amplification with faint, smeared products. The optimal DNA concentration for amplification of A. heterophyllus DNA was found to be $0.5 \mu \mathrm{L}$ of $1: 10$ dilution (approximately $0.6 \eta \mathrm{g}$ ), whilst the optimum annealing temperature was $35^{\circ} \mathrm{C}$.

\section{Amplified products and identification of fruit type- specific RAPD markers}

The approximate size of the amplified products of $A$. heterophyllus ranged from $350 \mathrm{bp}$ to $2.5 \mathrm{~kb}$ and the number of products generated per primer varied between 1 (OPA-17, OPE-14, OPH-09) and 11 (OPB-03, OPB-05). Products over $1.9 \mathrm{~kb}$ were not reproducible and were highly sensitive to the DNA concentration. The amplified products obtained with primers OPB-01 are shown in Figure 1, whilst the summary of the results obtained from a set of 100 primers used in the study is presented in Table 1 .

Only five primers(OPB-01, 02, 19, 20 and OPE-12) showed polymorphism for fruit type and were considered as useful markers to differentiate fruit types of $A$. heterophyllus. The reproducibility test was carried out for those five primers with 30 trees of each type, and the results showed that only the polymorphism detected with primer OPB-01 was consistently reproducible, whilst others showed inconsistent products in different intensities for both the fruit types. Based on these results, the VK fruit type was distinguishable by the presence or absence of one RAPD product (OPB-01-1.0 kb; Table 2). Despite the very low level of polymorphism between the two fruit types, polymorphism was observed between individuals with 26 primers (Table 1 ).

\section{DISCUSSION}

RAPD marker (OPB-01-1.0) could potentially be used to distinguish the two fruit types in $A$. heterophyllus (Figure 1; Table 2). The two fruit types of this tetraploid species are not consistently distinguishable on the basis of morphological traits of mature trees ${ }^{28,29}$. Furthermore, apart from firmness of the ripened flesh no morphological or phenological differences were observed between two fruit types in a study carried out on flowering and fruiting morphology and phenology ${ }^{5}$. The observation of a large number of common RAPD products (Table 1) may imply that the genetic base of $A$. heterophyllus in Sri Lanka is very narrow and it may be due to a limited initial gene pool since $A$. heterophyllus is an introduction to Sri Lanka.

Occurrence of two fruit types in A. heterophyllus may also be a result of different enzyme activities, or the inhibition of an enzyme/set of enzymes at fruit ripening. 
In many plant species, the process of fruit ripening and softening is largely the result of enzyme-mediated physico-chemical changes, which are genetically and developmentally regulated ${ }^{30}$. Therefore, differential gene expression patterns that are correlated with changes in growth and physiology have been a source of concern in many studies ${ }^{31-32}$. Results of such studies have revealed that fruit ripening occurs under the control of genes expressed during the ripening process. Studies on biochemical changes during the ripening of the VK and VL fruit types of $A$. heterophyllus revealed a common process of ripening in both the fruit types ${ }^{33-34}$.
It was also suggested that the differences in the texture of the flesh of the ripened syncarps are related to the degree of change of activities in enzymes such as pectin esterase and polygalacturonase towards the early ripening stage. These changes were more marked in the soft-fleshed type, and either arrested or delayed in the hard-fleshed fruit type. Although such evidence supported the developmental expression of enzymes (hence genes), little is known about the gene expression during fruit ripening in $A$. heterophyllus ${ }^{27}$. It may be possible to distinguish the two fruit types using isozymebanding patterns of pectin esterase and

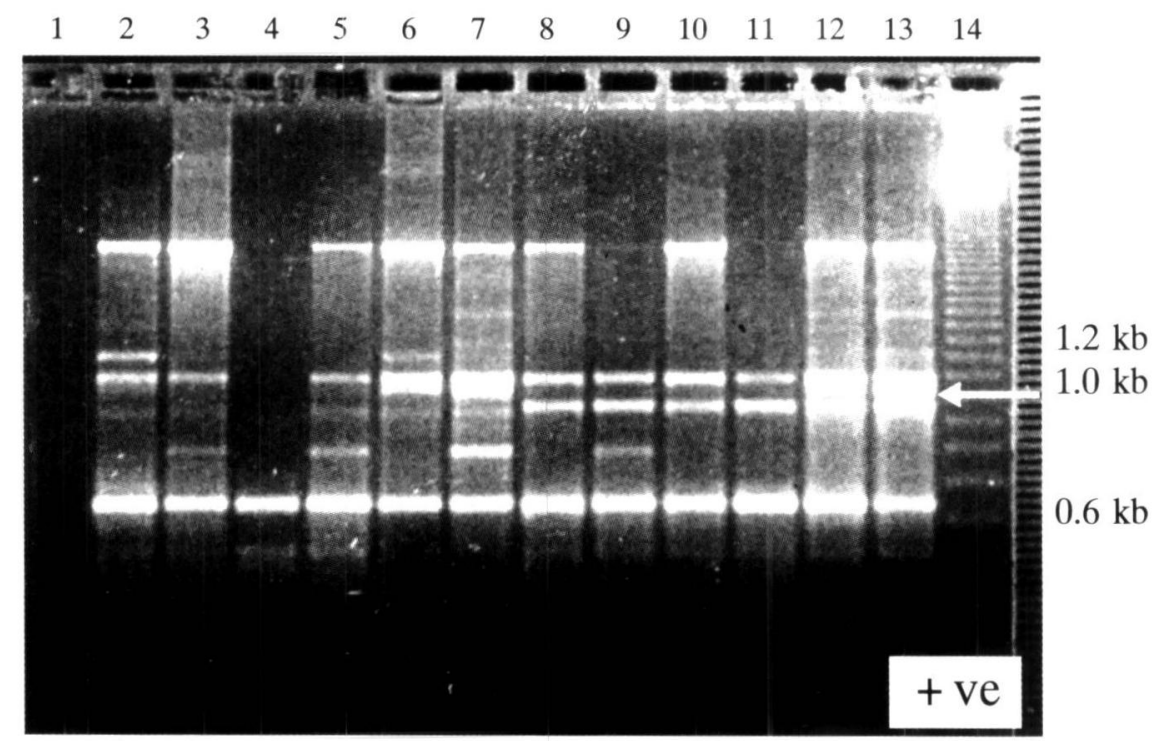

Figure 1: Gel electrophoresis of amplification products obtained with OPB-01 (5'GTTTCGCTCC3') primer.

Note: Lanes 2-7 and 8-13 represent individuals from soft- (VL) and hard-fleshed (VK) fruit types, respectively. The size of the molecular weight standards (123 bp DNA marker) in lane 14 is shown in kb whilst lane 1 represents the controlled amplification.

Table 1: Summary of primers used to test the occurrence of fruit type specific molecular markers in A. heterophyllus.

\begin{tabular}{|c|c|c|}
\hline Type of products & Number of primers & Primers \\
\hline Polymorphic for fruit types & 5 & OPB-01-02, 19-20; OPE-12 \\
\hline Polymorphic for individuals & 26 & $\begin{array}{l}\text { OPA- } 07-09,12,19-20 \text {; OPB-02-03, 05-08, 10, 16-17; OPE-09, 13, 17; } \\
\text { OPH-02, 04, 15, 19; OPX-06, 07, 09, } 13\end{array}$ \\
\hline Monomorphic for fruit types & 48 & $\begin{array}{l}\text { OPA-02, 04-06, 10-11, 14, 16-18; OPB-04-05, 11, 13-14; OPE-01-04, } \\
\begin{array}{l}11,14-16,19-20 ; \text { OPH-03, 05-07, 09, 12-14, 17-18, 20; OPX-01-02, } 05 \text {, } \\
08,10-12,16-20\end{array}\end{array}$ \\
\hline $\begin{array}{l}\text { Smeared and complicated bands } \\
\text { (difficult to reproduce) }\end{array}$ & 35 & $\begin{array}{l}\text { OPA-01 07-09, 12-13, 19-20; OPB-03,06-08, 10, 12, 16-18; OPE-05-06, } \\
08-09,13,17-18 \text {; OPH-01-02, } 04,08,11,15,19 ; \text { OPX-06-07, 09, } 13\end{array}$ \\
\hline No amplified products & 12 & OPA- 03,15 ; OPB- 09,15 ; OPE- 07,10 ; OPH- 10,16 ; OPX-03-04, 14- 15 \\
\hline
\end{tabular}


Table 2: RAPD marker used to distinguish fruit types in A. heterophyllus.

\begin{tabular}{lcc}
\hline & \multicolumn{3}{c}{ Fruit types } \\
\cline { 2 - 3 } RAPD marker & Hard-fleshed type (VK) & Soft-fleshed type (VL) \\
\hline OPB-01-1.0 & $(+)$ & $(-)$ \\
\hline
\end{tabular}

Note: Markers are assigned by primer number and product size is given in $\mathbf{k b}$.

$(+)$ and $(-)$ indicate presence and absence of marker, respectively.

polygalacturonase enzymes; but currently no staining solutions are available for these two enzymes. Furthermore, esterase showed inconsistent banding patterns in the isozyme study of mating system analysis of $A$. heterophyllus ${ }^{27}$. The success of this method may also depend on the plant material used for extraction of enzymes, since enzyme expression at early stages (e.g. in seedling leaf tissues, embryo) may not be the same as at later stages (e.g. in tissue from ripening syncarps). Isozyme analysis also showed low levels of polymorphism in A. heterophyllus, and only two out of $16(12.5 \%)$ enzyme systems were polymorphic ${ }^{27}$. There was no evidence for consistent fruit type-specific isozyme markers at the three loci scored. Majority of progenies were identified and almost all parents were predicted as heterozygotes ${ }^{27}$.

Based on the results of the study, varaka (hard) and vella (soft-fleshed) fruit types of $A$. heterophyllus may be distinguished using OPB-01-1.0 rapid marker. Cloning, sequencing and conversion of the RAPD marker to a SCAR marker for verification of the result and development of highly reproducible and easy markers for effective identification of fruit types at the early stage of growth are suggested.

\section{References}

1. Acedo A.L. (1992). Jackfruit biology, production, use, and Philippine research. Monograph number 1. Forestry/ Fuelwood Research and Development (F/FRED) Project. Winrock International Institute for Agricultural Development, USA.

2. Corner E.J.H. (1981). Moraceae. In: A Revised Handbook to the Flora of Ceylon. (Eds. M.D. Dassanayaka \& F.R. Fosberg). pp. 213-220. Amerind Publishing, New Delhi.

3. Morton J.F. (1965). The jackfruit, (Artocarpus heterophyllus Lam.): its culture, varieties and utilization. Proceeding of the Florida State Horticultural Society 78: 336-344.

4. Purseglove J.W. (1968). Tropical crops: Dicotyledons 2. John Wiley \& Sons Inc., New York.

5. Pushpakumara D.K.N.G. (1997). The reproductive biology of Artocarpus heterophyllus Lam. Unpublished Ph.D. Thesis, University of Oxford, Oxford, UK.

6. Yaacob O. \& Subhadrabandhu S. (1995). The production of economic fruit in south-east Asia. Oxford University Press, Oxford.
7. Soltis D.E. \& Soltis P.S. (1990). Isozymes in plant biology. Chapman \& Hall, London.

8. Tanksley S.D., Young N.D., Paterson A.H. \& Bonierbale M.W. (1989). RFLP mapping in plant breeding: new tools for an old science. Bio Technology 7: 257-264.

9. Welsh J. \& McClelland M. (1990). Fingerprinting genomes using PCR with arbitrary primers. Nucleic Acids Research 18: 7213-7218.

10. Williams J.G.K., Kubelik A.R., Livak K.J., Rafalski J.A. \& Tingey S.V. (1990). DNA polymorphisms amplified by arbitrary primers are useful as genetic markers. Nucleic Acids Research 18: 6531-6535.

11. Williams J.G.K., Hanafey M.K., Rafalski J.A. \& Tingey S.V. (1993). Genetic analysis using random amplified polymorphic DNA markers. Methods in Enzymology 218: 704-740.

12. Deragon J.M. \& Landry B.S. (1992). RAPD and other PCR-based analyses of plant genomes using DNA extracted from small leaf disks. PCR Methods \& Applications 1: 175-180.

13. Newbury H.J. \& Ford-Lloyd B.V. (1993). The use of RAPD for assessing variation in plants. Plant Growth Regulation 12: 43-51.

14. Hormaza J.I., Dollo L. \& Polito V.S. (1994). Identification of RAPD marker linked to sex determination in Pistacia vera using bulked segregant analysis. Theoretical \& Applied Genetics 89: 9-13.

15. Wright C.P., Penner G.A., O'Donoughue L.S., Burrows V.D., Molnar S.J. \& Fedak G. (1994). The identification of random amplified polymorphic DNA markers for day length insensitivity in oat. Genome 37: 910-914.

16. Hadrys H., Balick M. \& Schierwater B. (1992). Applications of random amplified polymorphic DNA (RAPD) in molecular ecology. Molecular Ecology 1: 55-63.

17. Stiles J.I., Lemme C., Sondur S., Morshidi M.B. \& Manshardt R. (1993). Using randomly amplified polymorphic DNA for evaluating genetic relationships among papaya cultivars. Theoretical \& Applied Genetics 85: 697-701.

18. Khadari B., Lashermes P. \& Kjellberg F. (1995). RAPD fingerprints for identification and genetic characterization of fig (Ficus carica L.) genotypes. Journal of Genetics \& Breeding 49: 77-86.

19. Koller B., Lehmann A., McDermott J.M. \& Gessler C. (1993). Identification of apple cultivars using RAPD markers. Theoretical \& Applied Genetics 85: 901-904. 
20. Schnell R.J., Ronning C.M. \& Knight R.J. (1995). Identification of cultivars and validation of genetic relationships in Mangifera indica $L$. using RAPD Markers. Theoretical \& Applied Genetics 90: 269-274.

21. Russell J.R., Hosein F., Johnson E., Waugh R. \& Powell W. (1993). Genetic differentiation of cocoa (Theobroma cacao L.) populations revealed by RAPD analysis. Molecular Ecology 2: 89-97.

22. Ayliffe M.A., Lawrence G.J., Ellis J.G. \& Pryor A.J. (1994). Heteroduplex molecules formed between allelic sequences cause nonparental RAPD bands. Nucleic Acids Research 22: 1632-1636.

23. Ellsworth D.L., Rittenhouse K.D. \& Honeycutt R.L. (1993). Artifactual variation in randomly amplified polymorphic DNA banding patterns. Bio Techniques 14: 214-217.

24. Harris S.A. (1995). Systematics and randomly amplified polymorphic DNA in the genus Leucaena (Legminosae, Mimosoideae). Plant Systematics \& Evolution 197: 195-208.

25. Heun M. \& Helentjaris T. (1993). Inheritance of RAPDs in $\mathrm{F}_{1}$ hybrids of corn. Theoretical \& Applied Genetics 85: 961-968.

26. Doyle J.J. \& Doyle J.L. (1987). A rapid DNA isolation procedure for small amounts of fresh leaf tissue. Phytochemistry Bulletin 19: 11-15.

27. Pushpakumara D.K.N.G., G.L.L.P. Silva, S.A. Harris \& H. Jianlin (2005). DNA extraction, PCR optimization and southern hybridization laboratory protocols for woody perennials: jakfruit (Artocarpus heterophyllus Lam.) and farm animals: cattle (Bos taurus, Bos indicus) and sheep (Ovis aries). CARP-ICRAF Tree Domestication Project of Sri Lanka, 114/9, Wijerama Mawatha, Colombo 7.

28. Pushpakumara D.K.N.G., Boshier D.H. \& Harris S.A. (1997). Mating system in Artocarpus heterophyllus Lam. Tropical Agricultural Research 9: 1-14.

29. Soepadmo E. (1991). Artocarpus heterophyllus Lamk. In: Plant resources of Southeast Asia No. 2: Edible Fruits and Nuts. (Eds. E.W.M. Verheij \& R.E. Coronel) pp. 86-91. PUDOC, Wageningen.

30. Brady C.J. (1987). Fruit ripening. Annual Review of Plant Physiology 38: 155-178.

31. Christoffersen R.E., Warm E. \& Laties G.G. (1982). Gene expression during fruit ripening in avocado. Planta 155: 52-57.

32. Oh B.J., Balint D.E. \& Giovannoni J.J. (1995). A modified procedure for PCR-based differential display and demonstration of use in plants for isolation of genes related to fruit ripening. Plant Molecular Biology Reporter 13: 70-81.

33. Matior Rahman A.K.M., Haq E., Mian.A.J. \& Chesson A. (1995). Microscopic and chemical changes occurring during the ripening of two forms of jackfruit (Artocarpus heterophyllus L.). Food Chemistry 52: 405-410.

34. Selvaraj Y. \& Pal D.K. (1989). Biochemical changes during the ripening of jackfruit (Artocarpus heterophyllus L.). Journal of Food Science \& Technology 26: 304-307. 